Geliş Tarihi:

14.07.2020

Kabul Tarihi:

02.05 .2021

Yayımlanma Tarihi:

25.06.2021
Kaynakça Gösterimi: Vurdu, S. A. (2021). Importance of services trade and a case on competitive advantages of Turkey. İstanbul Ticaret Üniversitesi Sosyal Bilimler Dergisi, 20(40), 331-357. doi: 10.46928/iticusbe.769054

\title{
IMPORTANCE OF SERVICES TRADE AND A CASE ON COMPETITIVE ADVANTAGES OF TURKEY
}

Araştırma

Selahattin Armağan Vurdu (D) $p$

Sorumlu Yazar (Correspondence)

İstanbul Maden ve Metaller İhracatçı Birlikleri (İMMİB)

armagan.vurdu@immib.org.tr

Selahattin Armağan Vurdu, İMMIB Genel Sekreteri olarak görev yapmakta ve sorumluluğu alanındaki sektörlerde Türkiye'nin ihracatını artırmaya yönelik faaliyetleri yönetmektedir. Aynı zamanda doktor öğretim görevlisi olarak İstanbul Ticaret Üniversitesi ve İstanbul Aydın Üniversitesinde uluslararası ticaret alanında ders vermektedir. 


\title{
IMPORTANCE OF SERVICES TRADE AND A CASE ON COMPETITIVE ADVANTAGES OF TURKEY
}

Selahattin Armağan Vurdu armagan.vurdu@immib.org.tr

\begin{abstract}
Purpose: The services sector has been emerging as a key driver of global trade rather than merchandise trade. Together with the re-shaping role of digitalization, ICT and ICT enabled services have been of high importance for the global growth and presenting opportunities both for developed and even more for developing economies. Telecommunications, computer and information, insurance and pension, financial services, intellectual property are emphasized for being more efficient on economic growth and after the Covid-19 pandemic outbroke, the importance of ICT and related services were highlighted due to the rapid digital transformation the pandemic has triggered. The purpose of this paper is to analyze Turkey's foreign trade competitiveness in ICT and ICT-enabled services comparing with the major exporters of aforementioned services.

Method: Competitiveness of Turkey, USA, India and China are compared in the trade in services by using competitive advantage indices RCA, RXA, RMP, RTA, RC.

Findings: Turkey has a surplus in its services trade, however, the sectors Turkey has competitiveness are travel and transport but not the ICT and ICT-enabled services. Digital transformation may help Turkey to both enable sustainable trade and faster recovery from pandemic.
\end{abstract}

Originality: Originality of the paper comes from the indication of necessity to change the mixture of Turkey’s trade in services and the literature lacks this kind of research.

Keywords: Covid-19, Pandemic, Services Trade, ICT, Digitalization, Competitive Advantage

JEL Classification: F10 


\section{HIZMETLER TÍCARETININ ÖNEMI VE REKABETÇİ AVANTAJLAR VAKA ÇALIŞMASI}

\section{ÖZET}

Amaç: Mal ticaretinden ziyade hizmetler sektörü, küresel ticaretin temel itici gücü olarak ortaya çıkmaktadır. Dijitalleşmenin yeniden şekillendirici rolüyle birlikte, BİT ve BİT destekli hizmetler, küresel büyüme açnısında hem gelişmiş ekonomiler hem de daha da çok gelişmekte olan ekonomiler için firsatlar sunmaktadır. Telekomünikasyon, bilgisayar ve bilişim, sigorta ve emeklilik, finansal hizmetler ve fikri mülkiyetin, ekonomik büyüme üzerinde daha verimli olduğu vurgulanmaktadır ve Covid-19 salgının tetiklediği hızlı dijital dönüşüm nedeniyle BíT ve ilgili hizmetlerin önemi vurgulanmaktadır. Bu makalenin amacı, Türkiye'nin BİT ve BíT destekli hizmetlerdeki dış ticaret rekabetçiliğini, yukarıda bahsedilen hizmetlerin başlıca ihracatçıları ile karşılaştırarak analiz etmektir.

Yöntem: Türkiye, ABD, Hindistan ve Çin'in hizmet sektörlerinde diş ticaret rekabet gücü, RCA, RXA, RMP, RTA, RC rekabet avantajı endeksleri kullanılarak karşılaştırılmıştır.

Bulgular: Türkiye hizmet ticaretinde dış ticaret fazlası vermektedir, ancak Türkiye'nin rekabet gücü olan sektörler seyahat ve ulaşımdır, BİT ve ilgili sektörler değildir. Dijital dönüşüm, Türkiye'nin hem sürdürülebilir ticareti sağlamasına hem de pandemiden daha hızlı toparlanmasına yardımcı olabilecektir.

Özgünlük: Makalenin özgünlüğü, Türkiye'nin hizmet ticaretinin karışımını değiştirme gerekliliğinin göstermesinden ve literatürde bu tür araştırmaların eksikliğinden gelmektedir.

Anahtar Kelimeler: Covid-19, Pandemi, Hizmet Ticareti, BIT, Dijitalleşme, Rekabetçi Üstünlük

JEL Sinıflandırması: F10 


\section{INTRODUCTION}

Services sectors have gained high importance for the economic output, employment, trade, social wellfare, and development of other services and merchandise sectors they are affiliated with. Trade of services has been growing faster than the goods trade in the recent years and thus transition to serviced-based are discussed by both developed and developing World. ICT services and the services enables via ICT are evaluated to have broader impact area on economies. Developments in technology have always brought changes in trade, and digitalization has been transforming the trade with a slow pace. The Covid-19 pandemic has been a a game changer in the year 2020 and acted as a catalysor in digitalization. The purpose of this paper is to analyze Turkey's foreign trade competitiveness in services trade in order to figure out whether Turkey is on the way to adapt the digitalized World with its production and presentation to the world or whether Turkey has been keeping to produce and serve the more traditional services. It is important to see the global need and change ahead and make policies in accord.

In the conceptual framework, firstly the concept of services is described in detail since it has complexity in general means, importance of the trade in services is explained by many aspects, and then the effects of the Covid-19 pandemic on the services are discussed giving focus on digitalization and ICT services. In the analytic part, competitiveness of Turkey in services trade is anaylized by comparing with the top ICT exporting countries, which are USA, China and India, using RCA, RXA, RMP, RTA, RC competitiveness indices. In the results and conclusion part, competitiveness results of Turkey are detailed and lastly policy recommendations are discussed.

\section{CONCEPTUAL FRAMEWORK}

\section{Trade in Services}

The services sector has been emerging as a key driver of global trade in the recent years and they have been the fastest growing sector. While world exports of merchandise trade have increased by $20 \%$ in value terms between the years 2008 and 2018, world exports of commercial services have increased by $46 \%$ in value terms in the same period (World Trade Organization [WTO], 2019) . The average annual growth rates of exports of manufactured goods and services have realized as $2.3 \%$ and $3.9 \%$, respectively, in 10 years. Moreover, according to WTO’s 2019 Report, WTO Global Trade Model run in 2019 indicated that services could account for up to 1/3 of world trade by the year 2040 . 


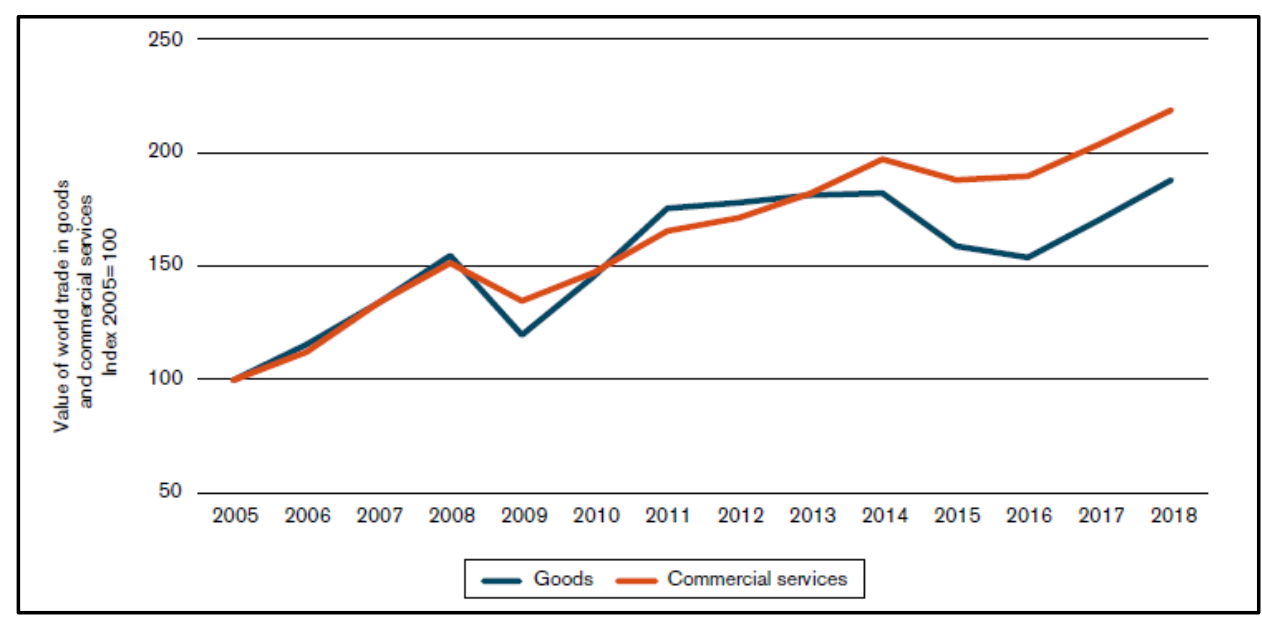

Figure 1: Growth of World Trade in Goods and Commercial Services

Source: World Trade Organization 2019 World Trade Report

After world goods trade grew by $2,9 \%$ in terms of quantity in 2018, it fell by $0,1 \%$ in 2019 due to the effects of trade tensions and slowing economic growth. The decrease in value of world goods trade, which was realized as 18,89 trillion dollars, was recorded as $3 \%$. On the other hand, service trade increased by $9 \%$ in 2018, but lost momentum in line with the decrease in goods trade in 2019. Services trade realized as 6,03 trillion dollars recording a growth rate of 2\% in 2019 (World Trade Organization, 2020).

\section{Context of Services}

International Monetary Fund's (IMF) context of Balance of Payments and International Investment Position Manual (BPM) is embraced for categorizing and reporting trade statistics in services. The BPM6 version (definitions and classification of the sixth (2009) edition) of the IMF Balance of Payments and International Investment Position Manual contains the following 12 standard services components as can be seen in the Table 1. By definition, "commercial services" comprise all services categories stated above except government goods and services, n.i.e.

Table 1: BPM6 Aggregated Service Components

\begin{tabular}{cl}
\hline Code & Service Label \\
\hline 1 & Manufacturing services on physical inputs owned by others \\
\hline 2 & Maintenance and repair services, n.i.e. \\
\hline 3 & Transport \\
\hline 4 & Travel \\
\hline 5 & Construction \\
\hline 6 & Insurance and pension services \\
\hline 7 & Financial services \\
\hline 8 & Charges for the use of intellectual property, n.i.e.
\end{tabular}




\begin{tabular}{cl}
\hline 9 & Telecommunications, computer and information services \\
\hline 10 & Other business services \\
\hline 11 & Personal, cultural and recreational services \\
\hline 12 & Government goods and services, n.i.e. \\
\hline Source: International Monetary Fund (2009)
\end{tabular}

Source: International Monetary Fund (2009)

WTO divides commercial services into 4 sub-categories as goods-related services, transport, travel, and other commercial services. As it is seen in the Figure 2 below, the largest portion of services trade is generated by the "other commercial services" category, then comes travel, and transport follows. Goods-related services have the smallest share each year but have been yet increasing.

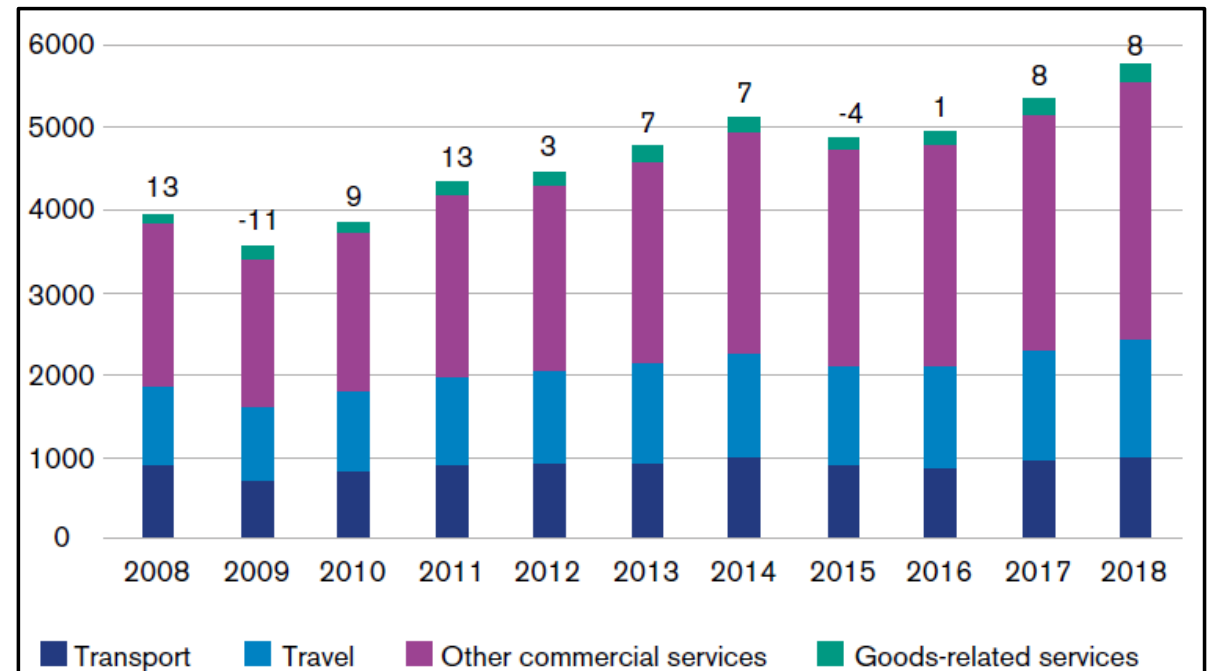

Figure 2: World Exports in Commercial Services by Sector(US\$ Billion) and Avg Annual Growth (\%) Source: WTO World Statistical Review 2019

The aggregated classification WTO uses is explained in the "Composition, definitions, methodology" document of the WTO World Trade Report (2019) in four main classes as shown below in Table 2. 
Table 2: WTO aggregation of services codes

\begin{tabular}{|c|c|c|}
\hline & Aggregated Class Name & Content of the aggregation \\
\hline 1 & Goods-Related Services & $\begin{array}{l}\text { Manufacturing services on physical inputs owned by others } \\
\text { (and paid a fee by the owner such as processing, assembly, } \\
\text { labelling, packing) and maintenance and repair services n.i.e. }\end{array}$ \\
\hline 2 & Transport & $\begin{array}{l}\text { Transport is the process of carriage of people and objects } \\
\text { from one location to another as well as related supporting and } \\
\text { auxiliary services. Transport can be classified according to: } \\
\text { (i) mode of transport, namely, sea, air, or other ("other” may } \\
\text { be further broken down into rail, road, internal waterway, } \\
\text { pipeline, and space transport as well as electricity } \\
\text { transmission); and (ii) what is carried - passengers or freight. } \\
\text { Also included are postal and courier services. }\end{array}$ \\
\hline 3 & Travel & $\begin{array}{l}\text { Travel credits cover goods and services - for own use or to } \\
\text { give away - acquired by non-residents from an economy } \\
\text { during visits to that economy. Travel debits cover goods and } \\
\text { services - for own use or to give away - acquired from other } \\
\text { economies by residents of the reporting economy during visits } \\
\text { to these other economies. The most common goods and } \\
\text { services covered are lodging, food and beverages, } \\
\text { entertainment and transportation (within the economy } \\
\text { visited), gifts and souvenirs. }\end{array}$ \\
\hline 4 & Othercommercial services & $\begin{array}{l}\text { The aggregate category “Other commercial services”' } \\
\text { includes the aforementioned IMF BMP6 components from } \\
\text { number } 5 \text { (construction) to number } 11 \text { (personal, cultural and } \\
\text { recreational services) . "Other business services” is an } \\
\text { inclusive sub-class within the "other commercial services” } \\
\text { and includes these value-added services: } \\
\text { - Research and development services consist of services that } \\
\text { are associated with basic and applied research, and } \\
\text { experimental development of new products and processes, } \\
\text { - Professional and management consulting services include } \\
\text { (a) legal services, accounting, management consulting, } \\
\text { managerial services, and public relations services; and (b) } \\
\text { advertising, market research, and public opinion polling } \\
\text { services, } \\
\text { - Technical, trade-related, and other business services include: } \\
\text { (a) architectural, engineering, and other technical services; (b) } \\
\text { waste treatment and depollution, agricultural, and mining } \\
\text { services; (c) operating leasing services; (d) trade-related } \\
\text { services; and (e) other business services n.i.e. }\end{array}$ \\
\hline
\end{tabular}

Source: WTO World Trade Report 2019

The crucial shortcoming the researchers conducting service trade analysis face with is that the services are intangible and they do not cross borders through customs, so measurement and analysis is difficult, comparability and coverage of data may not always be complete or the data might be compiled 
differently and thus inconsistencies may exist in the trade figures. It should be noted that while many economies worldwide have fully implemented the BPM6 for the recording of their Balance of Payments services transactions, some are still compiling their statistics according to the BPM5 methodology. Therefore, world and regional estimates of trade in new services items such as manufacturing services on physical inputs owned by others and maintenance and repair services n.i.e. may be underestimated, as some economies do not report these items yet. Furthermore, the international cooperation about services trade has some more path to go which results in the matters to trade in services be more complex than in goods trade. General Agreement on Trade in Services (GATS) commitments is by only 34\% with a higher commitments percentage in developed countries (by 66\%) and much less in least-developed countries (by 21\%) (World Trade Organization, 2019).

\section{Importance of the Trade in Services}

Trade in services matters globally for all developed, developing and least-developed countries because it can help economies achieve greater economies of scale, variety in output, more rapid growth, competitiveness and entrance into new markets which they cannot enter with goods exports; promote inclusiveness in terms of skills, gender, size and the location of economic activity, and provide a more efficient allocation of resources.

The importance of services for the economies does not come from only trade volumes they generate, but also from other economic aspects which the trade contributes as well. Services generate $65 \%$ of global GDP, attract over 2/3 of global foreign direct investment, and provide half of the global employment; $\% 75$ of the employment in high-income countries and $30 \%$ of the employment in LDCs (World Trade Organization, 2019). Considering the design of the developed economies, importance of services becomes apparently visible. In the light of these facts, it is not surprising that many developing economies have been going increasingly services-based. Developing economies generated $25 \%$ of world services exports and 34,4\% of world services imports in 2017. The speed of transition to services in developing economies has been even higher than in developed economies in some cases, and also services MSMEs in developing economies export more rapidly than manufacturing MSMEs (World Trade Organization, 2019).

In the history of international trade, technology has always set the milestones and changed the eras. Likely, according to the World Trade Report (2019), digital technologies are among the leading trends that will affect services trade in the future through creating new types of services trade like delocalized suppliers and/or not requiring physical presence, affecting the demand for services such as remotely delivered services, and disrupting trade in some services while creating new markets in areas such as environmental services. Moreover, ICT development means not only a unique sectoral trade’s growing but also some other sectors of whose trade relations are triggered by ICT developments are growing. The marginal cost of providing an additional unit approaches zero in ICT-enabled services sectors. This property of ICT-enabled sectors makes use of economies of scale and thus lowers trade 
costs by time (Fontagnéa, Mohnen, \& Wolf, 2014). Besides, the scientific and technical services provide input to agriculture, mining, utilities and construction and hence contribute to the growth of those sectors (Nayyar \& Hallward-Driemeier, 2018). In the light of these findings, it is obvious that ICT and ICT-enabled services contribute to developments other services and merchandise industries as well when they become digitally enriched.

The value of potentially ICT-enabled trade in services has increased by a factor of 1,6 in 10 years as shown in the figure below and reached up to 3 US\$ trillion with an unsatisfied high potential yet. In a study conducted by Euromonitor, it has been stated that smart wearable technologies are estimated to be a market of 23 US\$ billion by the year 2023 and what is more important is that, by the same year, the payments to be made via the smart wearables reach a value of 78 US\$ billion - 3 times of the market itself (Yamaguchi \& Teck, 2019).

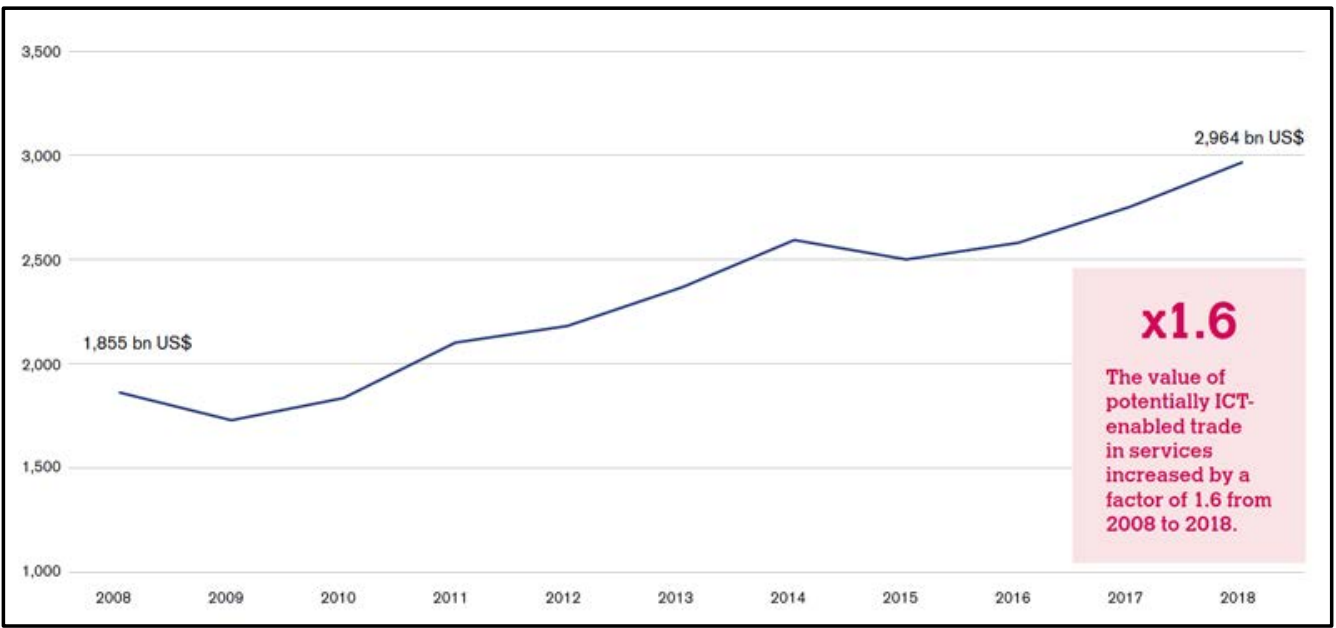

Figure 3: Growth of Share of Potentially ICT-Enabled Services in World Trade (US\$ Billion) Source: WTO World Statistical Review 2019

Digital technologies are estimated to change the trade flows on the global map for much like the benefit of developing countries. If developing countries could be able to adopt digital technologies, their share in global services trade could increase by about $15 \%$ while the share of services trade in global trade to be increasing by $50 \%$ by 2040 (World Trade Organization, 2019). Services trade creates a pathway for developing economies by digitalization on the way of development. In order to verify this statement, the top 10 ICT exporting countries of the year 2018 is examined. India as a lowincome country ranks second, and China as a country which accessed into upper-middle income group already in 2015 keeps the third place and with a 69\% change rate of exports. It should be noted that USA as a developed economy follows those two countries on ICT exporting rank. 


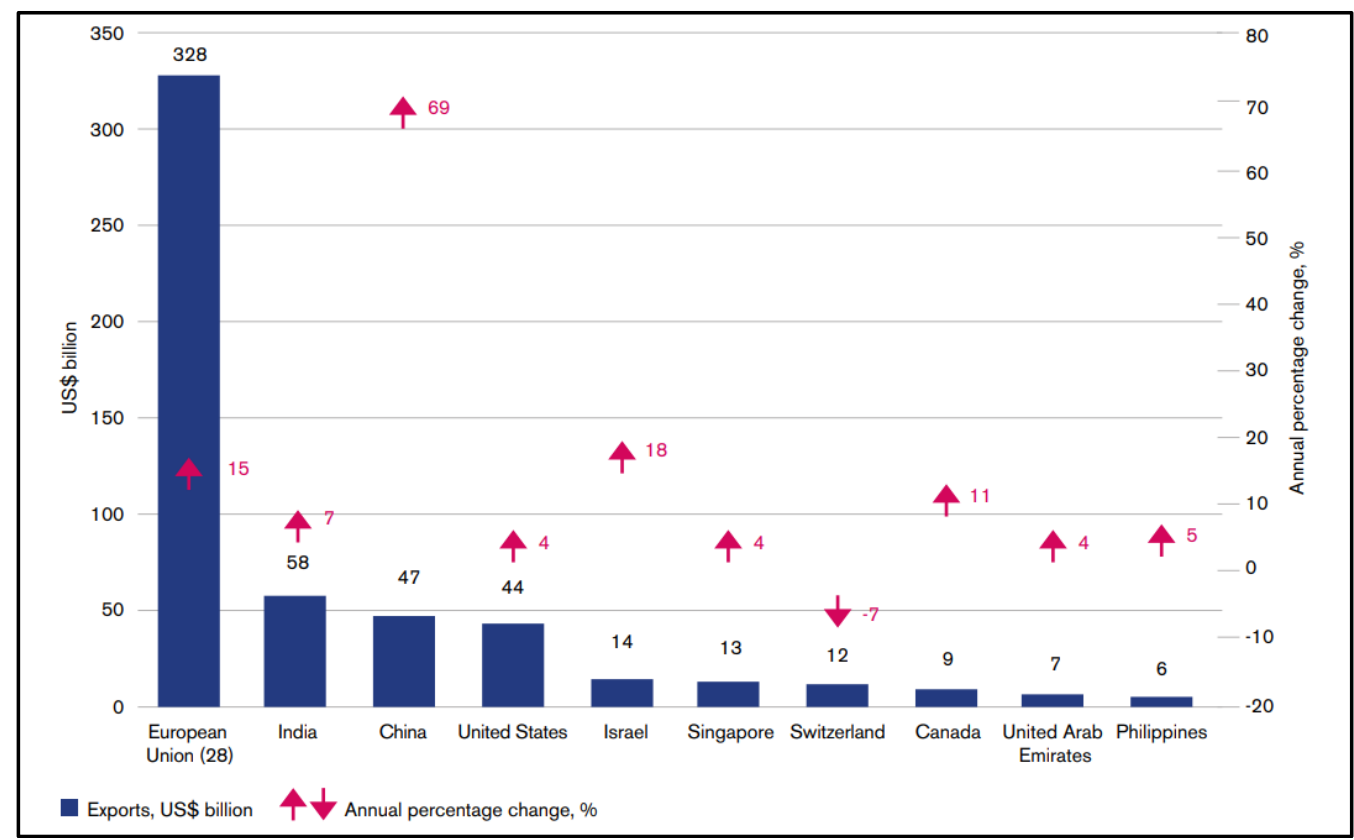

Figure 4: Leading ICT Exporters 2018 (US\$ Billion and Annual Percentage Change)

Source: WTO World Statistical Review 2019

As mentioned before, technological innovations, constituting new business models, have changed and are estimated to continue to change the nature and structure of services. According to UNCTAD's ICT Report (2015), some of the services in the IMF's aforementioned BMP6 classification have higher potentials for being delivered digitally due to their natures and hence have higher and faster impacts on the supplier countries'economies:

- insurance and pension services,

- financial services,

- charges for the use of intellectual property,

- telecommunications,

- computer and information services,

- other business services, and

- personal, cultural and recreational services

\section{The Effect of the Covid-19 Pandemic on the Services}

As people have been affected by Covid-19 pandemic around the world, the trade in all sectors was also affected either in a positive or negative way. While some businesses have been closed, others have welcomed new customers. Trade figures have been decreasing except some sectors which are crutial for fighting the pandemic. Food and medical goods (including pharmaceuticals, medical supplies such as alcohol, syringes, gauze and reagents etc, medical equipment and technology, personal protective products such as hand soap and sanitizer, face masks and protective spectacles) have been on the hot agenda of international trade (World Trade Organization, 2020). 
As Covid-19 crisis hit the globe, the services sectors have experienced a sudden stop due to the travel restrictions and curfew, shutdown and social distancing practices. WTO’s Services Trade Barometer is a medium-term indicator of world services trade activity, combining six component indices. Readings greater than 100 in the Services Trade Barometer indicates above trend growth and readings below 100 indicate below trend growth. The indices in the last service trade barometer published in March 2020 reflects expectations that Covid-19 would continue to weigh on services trade (World Trade Organization, 2020).

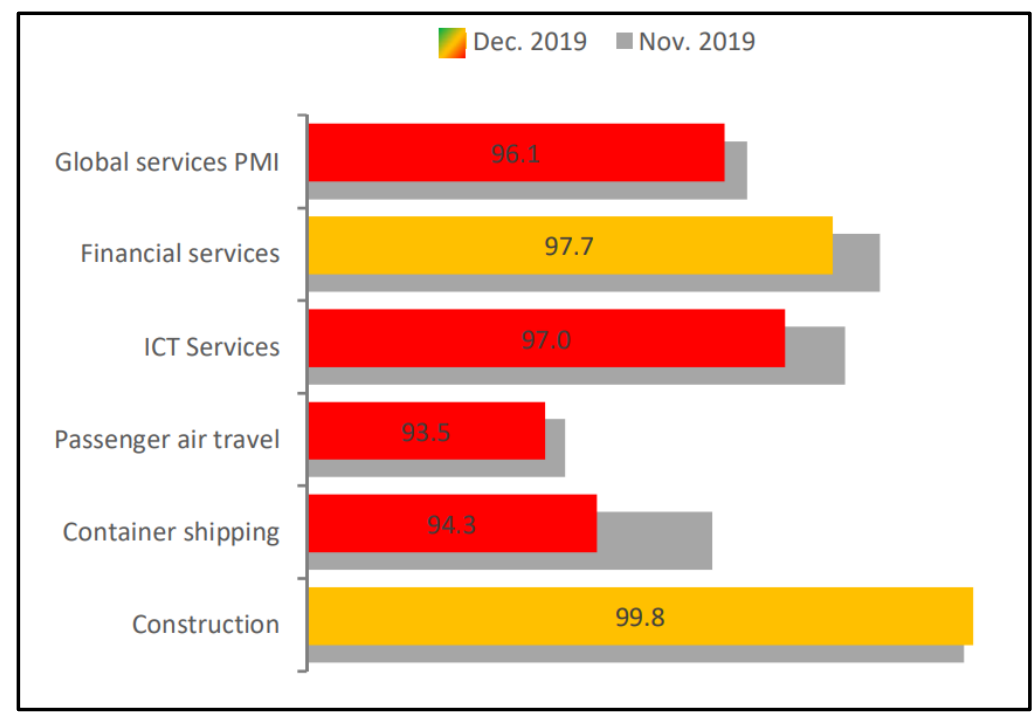

Figure 5: Components of Services Trade Barometer

Source: WTO Services Trade Barometer 2020 March Edition

Among the barometer's components, as can be seen in the Figure 5, the largest declines have been observed in passenger air travel and container shipping. Both indices cover the early developments stemming from the spread of the disease, which indeed intensified much more later.

Each pandemic had left traces in the history both on business levels and social levels. However, Covid-19 pandemic, which has influenced not only regional but also the whole world, has caused digitalization to enter into our lives. Having to do something in order to survive, the enterprises have switched to remote working, education activities has utilizes the online platforms, consumers have leant on contactless shopping and contactless socializing. Digitalization has been embraced by all segments of the global shakeholders with an unprecedented pace. Despite of varying from country to country and from enterprise to enterprise, the digital transformation took place in a period of one month on average, while the researches reveal that this stage would be achieved 108 years later without a pandemic (Ayanoğlu, 2020).

Below is presented a chart displaying the "ability" and the "need" of the sectors to work remotely. The ability concept is based on each occupation's level of interaction with computers, and the need concept is based on each occupation's level of physical proximity to other people. If remote working 
is necessary, then those occupations and businesses can adapt readily; otherwise it means the work location is fixed and cannot adapt easily. At the bottom of the figure, indicating the greater ability index and less need index, are software, professional services, telecommunications, banking, insurance, which comply with the suggestions of UNCTAD's ICT Report (2015) stated in the previous chapter.

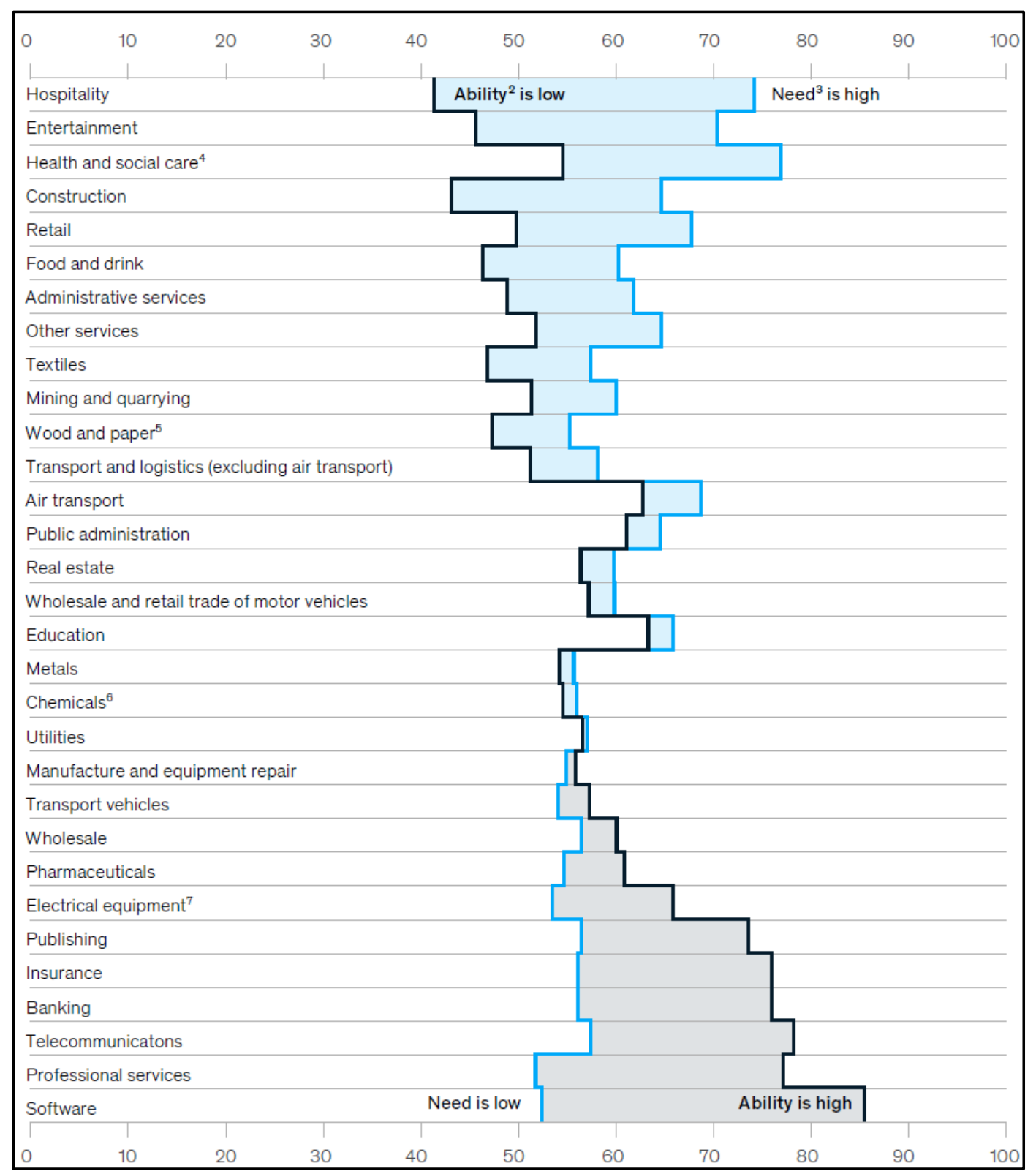

Figure 6: Difference Between Ability to Work Remotely and Need to Work Remotely, Index $(0=$ no need or ability)

Source: Allas, Sjatil, Stern, \& Windhagen (2020)

An article on Statista reveals the industries worst affected by the Covid-19 based on the employment data from Bureau of Labor Statistics (Richter, 2020), and as a result given that restaurants, bars and the like remained closed amid the lockdown, the leisure and hospitality sector has been hit hardest making the leisure and hospitality sectors leading the list which is also the first sector in the needability adaptabilty index in the study stated in Figure 6. 
Not surprisingly, the reality of Covid-19 pandemic ensured that the services which are more suitable to survive on remote work and social distancing conditions have been the ICT and ICT-enabled services, which in the end attributes of high importance to a country's competitiveness in those mentioned sectors. Because, ICT and ICT-enabled services leverages the knowledge capital up to intellectual capital, which is equivalent to the overal sum of all the know-how, competencies and skills an enterprise needs to maintain a sustainable competitive power (Ayanoğlu, 2020).

\section{METHOD}

In the previous sections, the services industries are introduced and trade statistics are interpreted. Services embody many subsectors and contribution of each of the subsectors to the competitiveness of a country differs. ICT and ICT-enabled services improves the competitiveness outlook of any country, and also ICT and ICT-enabled services are the services affected less from the Covid-19 pandemic since the ability to work remotely in these sectors are high, and demand for digitalization has increased with the pandemic thus demand for ICT and ICT-enabled services increased. In the analytical research section of this paper, foreign trade competitiveness of selected countries in service sub-sectors are analyzedThe aim of the anaylysis is to evaluate the factors of competitiveness and the quantification of their impact on the export efficiency of the services.

\section{Methodology}

For the evaluation of competitiveness of foreign trade, there have been many indicators on the basis of market or trade information. Competitiveness is a relative rate and indicators with the base of absolute market share gives limited information about the competitive position of a product or sector in the economy (Seymen, 2009).

The most widely used index to measure competitive power in the literature is the Revealed Comparative Advantage (RCA) index developed by Balassa (1965). However, by claiming that the RCA index only takes into account exports, Vollrath (1991) developed versions of RCA using import, trade volume, trade balance figures, and Revealed Comperative Advantage Index (RCA), Relative Export Advantage Index (RXA), Relative Import Penetration Index (RMP), Relative Trade Advantage Index (RTA) and Revealed Competitiveness Index (RC) are used in this paper. The brief explanations of the indices are presented with the i indicating country, $\mathrm{j}$ indicating sector, $\mathrm{X}$ indicating export volume, $\mathrm{M}$ indicating import volume, where $\mathrm{X}_{\mathrm{it}}$ refers to the country's total exports and $\mathrm{X}_{\mathrm{nt}}$ refers to the world total exports.

Revealed Comparative Advantage Index (RCA) represents the ratio of the sector's share of exports in the country to the share of that sector's exports in the world's total exports. The index aims to explain whether there is an apparent advantage difference, without going down the cause of comparative advantage among countries. The index value greater than 1 indicates that the sector in question in the research country is comparatively advantageous in competition. The formula is shown as below: 


$$
\operatorname{RCA}_{\mathrm{ij}}=\left(\mathrm{X}_{\mathrm{ij}} / \mathrm{X}_{\mathrm{it}}\right) /\left(\mathrm{X}_{\mathrm{nj}} / \mathrm{X}_{\mathrm{nt}}\right)
$$

The Relative Export Advantage Index (RXA) refers to the ratio of the share of a given sector's exports in the country's exports (excluding the relevant sector in the country's exports) to the share of the world's exports in the world's total exports (excluding the relevant sector in the world's total exports). The difference of RXA from RCA is that it prevents the relevant sector from taking into account twice. The index value greater than 1 indicates that the sector in question in the research country is comparatively advantageous in competition. The formula is shown as below:

$$
\operatorname{RXA}_{i j}=\left(X_{i j} / X_{i-t}\right) /\left(X_{-n j} / X_{-n-t}\right)
$$

Relative Import Penetration Index (RMP) is similar to the RXA in that the import data are included instead of export. RPM refers to the ratio of the share of imports of a particular sector in the country's imports (not including the relevant sector in the country's imports) to the share of the world's imports in the world's total imports (not including the relevant sector in the world's total imports). The interpretation of the value of the RPM is the opposite of the interpretation of the value of the RXA. The index value less than 1 indicates that the sector in question in the research country is comparatively advantageous in competition. The formula is shown as below:

$$
\operatorname{RMA}_{\mathrm{ij}}=\left(\mathrm{M}_{\mathrm{ij}} / \mathrm{M}_{\mathrm{i}-\mathrm{t}}\right) /\left(\mathrm{M}_{-\mathrm{nj}} / \mathrm{M}_{-\mathrm{n}-\mathrm{t}}\right)
$$

Relative Trade Avantage Index (RTA) is equal to the difference between the RXA and RTA. The index value greater than 0 indicates that the sector in question in the research country is comparatively advantageous in competition. The formula is shown as below:

$$
\text { RTA= RXA }- \text { RMA }
$$

Revealed Competitiveness Index (RC) indicates the difference between the natural logarithmic values of RXA and RMP. An index value greater than 0 indicates a competitive advantage. The formula is shown as below:

$$
\mathrm{RC}=\ln \mathrm{RXA}-\ln \mathrm{RMP}
$$

\section{Sampling in the Research}

Turkey, USA, India and China are to be analyzed in this paper. India and China are chosen to compare with Turkey because these countries are highly competitive in the most value-adding subsectors, which are the ICT and ICT-enabled services. USA is included in the study because it is a highly competitive country in general means.

\section{Data Gathering}

Services export and import data are retrieved from ITC Trademap which is a reliable data portal presenting consolidated trade data from WTO dataset and national sources, like TurkStat for Turkish data, however may take updates national sources with delay. BMP6 revision has been implemented 
with level 1 (as it was shown in Table 1 in the previous chapters). The more detailed levels are examined within this study however, because of the blank data cells, the increasing notifications of compiling to be done in different ways caused much complexity, high standard variations. In order to enable a smooth and clear result table, the 12-component aggregated list has been preferred. Due to the lack of consistencies in data grouping, it should be considered that USA data may be misleading because Trademap ITC does not report data for USA in Code 1 services. However, USA was not excluded from the sample intentionally for the reason that it is by far the largest services exporter of the World and it shows a strong competitiveness in financial services when compared to other countries in the sample. Some countries has records as "not specified services", those figures are neglected. It should be noted that world value is almost always incomplete because always there is at least one country which has not reported trade data for the selected service.

\section{Data Analysis}

The years in between 2015-2019 have been selected as time interval of the study in data retrieval and then the averages of the export and import statistics have been taken. The average trade statistics, countries' percentages in global export, export/import coverage ratios can be found in the Appendix in detail, and the summary is shown in Table 3 as below.

Table 3: Summary of the 4 Countries’ Services Trade (US\$ Billion)

\begin{tabular}{ccccc}
\hline Country & Export & Import & Trade Balance & Trade Volume \\
\hline USA & 823,51 & 540,98 & 282,52 & 1364,49 \\
\hline China & 242,18 & 476,21 & $-234,03$ & 718,39 \\
\hline India & 184,54 & 153,39 & 31,16 & 337,93 \\
\hline Turkey & 55,84 & 26,89 & 28,96 & 82,73 \\
\hline
\end{tabular}

Source: Based on author’s calculations with data retrieved from ITC Trademap database

The competitiveness indices of the countries are calculated and colored tables are created to highlight the areas indicating competitive advantage in foreign trade.

China has been set as the second leading ICT exporter in the previous chapter. It is a sizeable exporter and importer in services and it has trade deficit. USA has the largest exporter and importer of the services with a significant trade surplus. India and Turkey have smaller trade figures with trade surpluses. 


\section{RESULTS}

As shown in the Figure 7 below, Turkey's competititive advantage seem high especially in travel, transport and construction services. Contsruction exports have been losing power year by year, but the high levels of the earlier years taken into calculation hightens the average. On the other hand, all the super powers of Turkey are under threat due to the Covid-19 pandemic.

\begin{tabular}{|c|c|c|c|c|c|c|}
\hline Code & Service Label & RCA & RXA & RMP & RTA & RC \\
\hline 1 & $\begin{array}{l}\text { Manufacturing services on physical } \\
\text { inputs owned by others }\end{array}$ & 0,30 & 0,29 & 0,24 & 0,05 & 0,19 \\
\hline 2 & Maintenance and repair services n.i.e. & 1,06 & 1,06 & 2,83 & $-1,77$ & $-0,98$ \\
\hline 3 & Transport & 2,33 & 3,22 & 1,85 & 1,37 & 0,56 \\
\hline 4 & Travel & 1,86 & 2,53 & 0,69 & 1,84 & 1,30 \\
\hline 5 & Construction & 0,53 & 0,52 & 0,25 & 0,27 & 0,73 \\
\hline 6 & Insurance and pension services & 0,95 & 0,95 & 3,74 & $-2,79$ & $-1,37$ \\
\hline 7 & Fin ancial services & 0,12 & 0,11 & 0,49 & $-0,38$ & $-1,50$ \\
\hline 8 & $\begin{array}{l}\text { Charges for the use of intellectual } \\
\text { property n.i.e. }\end{array}$ & 0,03 & 0,02 & 1,01 & $-0,99$ & $-3,77$ \\
\hline 9 & $\begin{array}{l}\text { Telecommunications, computer, } \\
\text { and information services }\end{array}$ & 0,22 & 0,21 & 0,77 & $-0,57$ & $-1,32$ \\
\hline 10 & Other business services & 0,24 & 0,20 & 0,71 & $-0,51$ & $-1,29$ \\
\hline 11 & $\begin{array}{l}\text { Personal, cultural, and } \\
\text { recreational services }\end{array}$ & 0,20 & 0,20 & 0,42 & $-0,22$ & $-0,74$ \\
\hline 12 & Government goods and services n.i.e. & 1,13 & 1,13 & 3,50 & $-2,37$ & $-1,13$ \\
\hline
\end{tabular}

Figure 7: Foreign Trade Competitiveness Indices of Turkey

Source: Indices are Calculated and the Cells are Colored by the Author According to the Interpretations of the Indices

As shown in the Figure 8 below, all of the foreign trade competitiveness incides point out the competitive advantage of China in manufacturing, maintenance and repair services which are goods related services; also telecommunications, computer and information services, and other business services (including Research and development, professional and management consulting services, architectural, engineering, and other technical services; waste treatment and depollution, agricultural, 
and mining services; operating leasing services; trade-related services). China has been increasing construction exports rapidly and the trade valuation methology of this series has changed in 2017, however since construction is not on the short list of this study, this fact will not be on the course to deepen in.

\begin{tabular}{|c|c|c|c|c|c|c|}
\hline Code & Service Label & RCA & RXA & RMP & RTA & $\mathbf{R C}$ \\
\hline 1 & $\begin{array}{l}\text { Manufacturing services on physical } \\
\text { inputs owned by others }\end{array}$ & 4,10 & 4,37 & 0,02 & 4,35 & 5,28 \\
\hline 2 & Maintenance and repair services n.i.e. & 1,60 & 1,62 & $\mathbf{0 , 3 0}$ & 1,32 & 1,69 \\
\hline 3 & Transport & 0,95 & 0,94 & 1,20 & $-0,25$ & $-0,24$ \\
\hline 4 & Travel & 0,70 & 0,64 & 3,82 & $-3,18$ & $-1,78$ \\
\hline 5 & Construction & 4,78 & 5,15 & 1,01 & 4,14 & 1,63 \\
\hline 6 & Insurance and pension services & 0,80 & 0,80 & 0,98 & $-0,18$ & $-0,20$ \\
\hline 7 & Financial services & 0,16 & 0,15 & 0,05 & $\mathbf{0 , 1 0}$ & 1,11 \\
\hline 8 & $\begin{array}{l}\text { Charges for the use of intellectual } \\
\text { property n.i.e. }\end{array}$ & 0,24 & 0,22 & 0,90 & $-0,68$ & $-1,39$ \\
\hline 9 & $\begin{array}{l}\text { Telecommunications, computer, and } \\
\text { information services }\end{array}$ & 1,48 & 1,57 & 0,37 & 1,20 & 1,46 \\
\hline 10 & Other business services & 1,20 & 1,27 & 0,36 & 0,90 & 1,25 \\
\hline 11 & $\begin{array}{l}\text { Personal, cultural, and recreational } \\
\text { services }\end{array}$ & 0,30 & 0,29 & 0,46 & $-0,17$ & $-\mathbf{0 , 4 5}$ \\
\hline 12 & Government goods and services n.i.e. & 0,46 & 0,46 & 0,55 & $-0,09$ & $-0,18$ \\
\hline
\end{tabular}

Figure 8: Foreign Trade Competitiveness Indices of China

Source: Indices are Calculated and the Cells are Colored by the Author According to the Interpretations of the Indices

As shown in the Figure 9 below, all of the foreign trade competitiveness incides singles out the competitive advantage of India in telecommunications, computer and information services, and other business services (including Research and development, professional and management consulting services, architectural, engineering, and other technical services; waste treatment and depollution, agricultural, and mining services; operating leasing services; trade-related services). 


\begin{tabular}{|c|c|c|c|c|c|c|}
\hline Code & Service Label & RCA & RXA & RMP & RTA & $\mathbf{R C}$ \\
\hline 1 & $\begin{array}{l}\text { Manufacturing services on } \\
\text { physical inputs owned by others }\end{array}$ & 0,05 & 0,05 & 0,02 & $\mathbf{0 , 0 3}$ & 1,14 \\
\hline 2 & $\begin{array}{l}\text { Maintenance and repair services } \\
\text { n.i.e. }\end{array}$ & 0,06 & 0,06 & 0,26 & $-0,20$ & $-1,48$ \\
\hline 3 & Transport & 0,55 & 0,50 & 2,97 & $-2,47$ & $-1,78$ \\
\hline 4 & Travel & 0,59 & 0,53 & 0,45 & 0,08 & 0,16 \\
\hline 5 & Construction & 0,69 & 0,69 & 0,58 & 0,12 & 0,18 \\
\hline 6 & Insurance and pension services & 0,54 & 0,53 & 1,70 & $-1,17$ & $-1,16$ \\
\hline 7 & Financial services & 0,31 & 0,29 & 0,28 & $\mathbf{0 , 0 1}$ & 0,03 \\
\hline 8 & $\begin{array}{l}\text { Charges for the use of intellectual } \\
\text { property n.i.e. }\end{array}$ & 0,05 & 0,05 & 0,62 & $-0,57$ & $-2,52$ \\
\hline 9 & $\begin{array}{l}\text { Telecommunications, computer, } \\
\text { and information services }\end{array}$ & 3,08 & 4,02 & 0,38 & 3,64 & 2,36 \\
\hline 10 & Other business services & 1,48 & 1,72 & 1,10 & 0,62 & 0,45 \\
\hline 11 & $\begin{array}{l}\text { Personal, cultural, and } \\
\text { recreational services }\end{array}$ & 0,68 & 0,68 & 1,11 & $-0,43$ & $-0,49$ \\
\hline 12 & $\begin{array}{l}\text { Government goods and services } \\
\text { n.i.e. }\end{array}$ & 0,25 & 0,25 & 0,44 & $-0,19$ & $-0,57$ \\
\hline
\end{tabular}

Figure 9: Foreign Trade Competitiveness Indices of India

Source: Indices are Calculated and the Cells are Colored by the Author According to the Interpretations of the Indices

As shown in the Figure 10 below, the USA has a strong competitiveness in the financial services as all the indices indicate, and the intellectual property-related charges. However, it should also be noted that the U.S. Bureau of Economic Analysis records film and television tape distribution services under charges for the use of intellectual property n.i.e (rather than under audiovisual and related services). Code 1 is not applicable for USA. 


\begin{tabular}{|c|c|c|c|c|c|c|}
\hline Code & Service Label & RCA & RXA & RMP & RTA & $\mathbf{R C}$ \\
\hline 1 & $\begin{array}{l}\text { Manufacturing services on physical } \\
\text { inputs owned by others }\end{array}$ & & & & & \\
\hline 2 & Maintenance and repair services n.i.e. & 1,78 & 1,80 & 13,61 & $-11,81$ & $-2,02$ \\
\hline 3 & Transport & 0,62 & $\mathbf{0 , 5 7}$ & 1,35 & $-0,78$ & $-0,86$ \\
\hline 4 & Travel & 0,99 & 0,99 & 0,01 & 0,98 & 4,30 \\
\hline 5 & Construction & 0,16 & 0,16 & 5,32 & $-5,16$ & $-3,49$ \\
\hline 6 & Insurance and pension services & 0,87 & 0,87 & 2,99 & $-2,12$ & $-1,24$ \\
\hline 7 & Financial services & 1,74 & 1,87 & 0,87 & 1,00 & 0,77 \\
\hline 8 & $\begin{array}{l}\text { Charges for the use of intellectual } \\
\text { property n.i.e. }\end{array}$ & 2,10 & 2,28 & 1,16 & 1,12 & 0,67 \\
\hline 9 & $\begin{array}{l}\text { Telecommunications, computer, and } \\
\text { information services }\end{array}$ & 0,57 & 0,55 & 2,15 & $-1,60$ & $-1,37$ \\
\hline 10 & Other business services & 0,91 & 0,88 & 0,11 & 0,77 & 2,09 \\
\hline 11 & $\begin{array}{l}\text { Personal, cultural, and recreational } \\
\text { services }\end{array}$ & 2,27 & 2,31 & 3,31 & $-1,00$ & $-0,36$ \\
\hline 12 & Government goods and services n.i.e. & 1,92 & 1,94 & 3,26 & $-1,32$ & $-0,52$ \\
\hline
\end{tabular}

Figure 10: Foreign Trade Competitiveness Indices of USA

Source: Indices are Calculated and the Cells are Colored by the Author According to the Interpretations of the Indices

The services which have higher potential for being delivered digitally acc. to UNCTAD (2015) are listed to remind so that the three countries will be compared in this means:

- insurance and pension services,

- financial services,

- charges for the use of intellectual property,

- telecommunications,

- computer and information services,

- other business services, and

- personal, cultural and recreational services 
In line with the information given in a previous chapter that USA, China and India have ranked high in the ICT exporters, they show high competitive advantages in the codes 7, 9 and 10. On the other hand, Turkey has not yet emerged as a global ICT supplier and hence when compared with China, India and USA, it is weak in competitiveness in those areas. Nevertheless, Turkey indicates strenght in competition in codes 1,2,3,4.

\section{CONCLUSION, DISCUSSION AND RECOMMENDATIONS}

The services sector has been emerging as a key driver of global trade. They have been the fastest growing sector on the globe. Trade in services matters globally for all developed, developing and least-developed countries because it can help economies achieve growth at a faster pace and more inclusively. Developed countries have already been more into services sectors and many developing economies have been going increasingly services-based. Services sectors has the power to act as a key for developing countries to achieve as much as developed countries can. However, due to the slowing global economic growth and the decrease in goods trade, services trade also lost its acceleration in 2019, however still has kept increasing until the Covid-19 pandemic outbreak.

As technology has always set the milestones in the history of international trade, the recent digital technologies have changed and continue to change the economies and businesses as well. When the trends that will affect services trade in the future have been projected, digital technologies have always been among the leading trends. Services trade combined with digitalization creates a pathway for hiking of developing economies. In order to verify this statement, the top 10 ICT exporting countries are examined. India as a low-income country ranks second, and China as a country which accessed into upper-middle income group already in 2015 keeps the third place and with a 69\% change rate of exports. USA is among the top ICT exporters as a developed country. The three countries playing on the first league of the global trade are from different levels in terms of income and development. This reality can be regarded as the provision of the game-changer role of ICT and ICT related and enables services.

On the other hand, Covid-19 pandemic highlighted digitalization as a tool to to survive. Remote working, online learning, online shopping and socializing have suddently become the normal way of living. Digitalization has been embraced by all segments of the global shakeholders with a fast pace and this fact has driven demand for ICT services. Some of the services have been singled out to have higher and faster impacts on the supplier countries'economies because they have have higher potentials for being delivered digitally and these very services are insurance and pension services, financial services, charges for the use of intellectual property, telecommunications, computer and information services, other business services, and personal, cultural and recreational services. Those mentioned sectors have become even more important and needed amid the pandemic in order to retain businesses and personal lives. The countries who have competitiveness in those fields, the companies 
already operating within those fields and the ones who adopted this understanding fast have achieved against the pandemic in business means.

In the analytic case of the study, competitiveness of USA, Turkey, India and China in service sectors are analyzed through Revealed Comperative Advantage Index (RCA) developed by Balassa (1965), and Relative Export Advantage Index (RXA), Relative Import Penetration Index (RMP), Relative Trade Advantage Index (RTA) and Revealed Competitiveness Index (RC) developed by Vollrath (1991). The purpose with the analysis is to examine of the factors of competitiveness and the quantification of their impact on the export efficiency of the services and to observe whether Turkey has competitive power in the most value-adding subsectors, which are the ICT and ICT-enabled services. The results showed that Turkey's competititve advantage seem high especially in travel, transport and construction services which are among the worst affected services due to the Covid-19 pandemic. With a surplus in services trade, Turkey is considered a service provider. However, the study points out that Turkey has a strength on more traditional service sub-sectors and more valueadded services with a broader impact area should be focused on. Higher adoption of digital mindset, incentives and efforts to expand in ICT-enabled fields would help to make Turkey's trade performance sustainable and contribute to the post-pandemic economic recovery as well.

The analysis has some limitations due to the data avalailability, data coverage and classification of services trade. It is known that services trade data are not currently fully recorded, or compiled the same way in all countries. Therefore, inconsistencies may exist in the trade figures taken into the analysis.

Mostly due to the data problem and partially due to the consideration that trade in services is more complex than in merchandise trade and lacks a ground international cooperation, the literature related to trade in services is not as developed as the literature related to merchandise trade. Competitive analysis is heavily implemented for merchandise trade but research are not so frequent on competitiveness in services trade. This study aims to contribute to the literature on this regard. For further research, the relationship between traditional sectors and digital sectors could be observed and the way they are fed by each other could be analyzed. Along with the Covid-19 pandemic, even the sectors perceived the most traditional have digitalized to various extends. Through servicification, industrial sectors contain more services within them. All these facts underline the importance of ICT and ICT enabled services in economic development by both manufacturing and foreign trade. Therefore, the impact analysis on interdependencies of the sectors could lead to effective policies to be benefited by governements and private sector. 


\section{REFERENCES}

Allas, T., Sjatil, P. E., Stern, S., \& Windhagen, E. (April 29, 2020). How European businesses can position themselves for recovery. Retrieved June 23, 2020, from https://www.mckinsey.com/industries/public-sector/our-insights/how-european-businessescan-position-themselves-for-recovery.

Ayanoğlu, F. (2020). Dijital devrim, yeni dünya düzeni ve entelektüel sermaye. In S. Öz, D. Celayir, \& F. S. Onursal (Eds), Pandemi sonrası yeni dünya düzeninde teknoloji yönetimi ve insani dijitalizasyon (pp. 14-41). İstanbul: Hiperyayın.

Balassa, B. (1965). Trade liberalization and revealed comparative advantage. The Manchester School of Economic and Social Studies, 33(2), 99-123.

Fontagnéa, L., Mohnen, P., \& Wolf, G. (2014). No industry, no future?. French Council of Economic Analysis. Retrieved from https://hal.archives-ouvertes.fr/hal-01299902/document .

International Monetary Fund. (2009). Balance of Payments and International Investment Position Manual. (6). Retrieved from https://www.imf.org/external/pubs/ft/bop/2007/pdf/bpm6.pdf.

İnce, A. R., \& Erol, Y. (2014). Türk plastik sektörünün uluslararası rekabetçilik düzeyinin analizi. Akdeniz I.I.B.F. Dergisi,14 (29), 1-21. Retrieved from https://dergipark.org.tr/tr/pub/auiibfd/issue/32333/359296

Nayyar, G., \& Hallward-Driemeier, M. (2018).Trouble in the making? The future of manufacturingled development. Washington, DC: World Bank. doi:10.1596/978-1-4648-1174-6.

Richter, F. (2020, May 11). The industries worst affected by the COVID-19 job crisis. Retrieved June 1, 2020, from https://www.statista.com/chart/21669/unemployed-persons-in-the-us-byindustry .

Seymen, D. (2009). Türkiye'nin dış ticaret yapısı ve rekabet gücü [PDF document]. Retrieved from https://kisi.deu.edu.tr/dilek.seymen/end_ici_end_arasi_tic_tablolar.pdf.

United Nations Conference on Trade And Development. (2015). International trade in ICT services and ICT-enabled services. $\quad$ Retrieved from https://unctad.org/en/PublicationsLibrary/tn_unctad_ict4d03_en.pdf.

Vollrath, T. (1991). A theoretical evaluation of alternative trade intensity measures of revealed comparative advantage. Weltwirtschaftliches Archiv, 127(2), 265-280. Retrieved from http://www.jstor.org/stable/40439943.

World Trade Organization. (2019). Composition, definitions, methodology. Retrieved from https://www.wto.org/english/res_e/statis_e/wts2019_e/wts2019chapter07_e.pdf.

World Trade Organization. (2019). World statistical review. Retrieved September 13, 2019, from https://www.wto.org/english/res_e/statis_e/wts2019_e/wts2019_e.pdf.

World Trade Organization. (2019). World trade report. Retrieved from https://www.wto.org/english/res e/booksp_e/01 wtr19 0 e.pdf.

World Trade Organization. (2020, March 11). Services trade barometer. Retrieved June 15, 2020, from https://www.wto.org/english/news_e/news20_e/wtoi_11mar20_e.pdf.

World Trade Organization. (2020, April 3). Trade in medical goods in the context of tackling covid19. Retrieved June 15, 2020, from https://www.wto.org/english/news_e/news20_e/rese_03apr20_e.pdf. 
World Trade Organization. (2020, April 30). Trade set to plunge as covid-19 pandemic upends global economy. $\quad$ Retrieved June 15, 2020, from https://www.wto.org/english/news e/pres20_e/pr855_e.htm.

Yamaguchi, H., \& Teck, L. W. (2019, September). Consumer electronics 2024: Trends and opportunities [Video]. Webinar available from https://go.euromonitor.com/webinarconsumerelectronics-2019-consumer electronics in 2024.html. 


\section{APPENDIX}

Table 4: Turkey’s Service Trade Statistics (US\$ Million) (2015-2019 Years Average)

\begin{tabular}{|c|c|c|c|c|c|c|}
\hline Code & Service Label & $\begin{array}{l}\text { Turkey's } \\
\text { Export } \\
\text { Value }\end{array}$ & $\begin{array}{l}\text { Global } \\
\text { Export } \\
\text { Value }\end{array}$ & $\begin{array}{c}\text { Turkey's } \\
\text { Percentage } \\
\text { in Global } \\
\text { Export } \\
\end{array}$ & $\begin{array}{l}\text { Turkey's } \\
\text { Import } \\
\text { Value }\end{array}$ & $\begin{array}{c}\text { Export/ } \\
\text { import } \\
\text { coverage ratio }\end{array}$ \\
\hline 1 & $\begin{array}{l}\text { Manufacturing } \\
\text { services on physical } \\
\text { inputs owned by } \\
\text { others }\end{array}$ & 330,20 & $110.102,36$ & $0,30 \%$ & 132,00 & $250,15 \%$ \\
\hline 2 & $\begin{array}{l}\text { Maintenance and } \\
\text { repair services n.i.e. }\end{array}$ & 979,00 & $91.282,69$ & $1,07 \%$ & $1.218,80$ & $80,32 \%$ \\
\hline 3 & Transport & $22.307,40$ & $948.574,75$ & $2,35 \%$ & $7.426,20$ & $300,39 \%$ \\
\hline 4 & Travel & $24.577,20$ & $1.313 .777,68$ & $1,87 \%$ & $4.735,80$ & $518,97 \%$ \\
\hline 5 & Construction & 546,20 & $103.133,32$ & $0,53 \%$ & 127,80 & $427,39 \%$ \\
\hline 6 & $\begin{array}{l}\text { Insurance and } \\
\text { pension services }\end{array}$ & $1.247,60$ & $130.124,67$ & $0,96 \%$ & $2.220,40$ & $56,19 \%$ \\
\hline 7 & Financial services & 581,80 & $484.421,60$ & $0,12 \%$ & $1.208,20$ & $48,15 \%$ \\
\hline 8 & $\begin{array}{l}\text { Charges for the use } \\
\text { of intellectual } \\
\text { property n.i.e. }\end{array}$ & 93,60 & $370.784,20$ & $0,03 \%$ & $1.818,80$ & $5,15 \%$ \\
\hline 9 & $\begin{array}{l}\text { Telecommunications, } \\
\text { computer, and } \\
\text { information services }\end{array}$ & $1.260,80$ & $557.870,05$ & $0,23 \%$ & $2.137,80$ & $58,98 \%$ \\
\hline 10 & $\begin{array}{l}\text { Other business } \\
\text { services }\end{array}$ & $2.949,20$ & $1.228 .542,63$ & $0,24 \%$ & $4.521,20$ & $65,23 \%$ \\
\hline 11 & $\begin{array}{l}\text { Personal, cultural, } \\
\text { and recreational } \\
\text { services }\end{array}$ & 146,00 & $71.352,91$ & $0,20 \%$ & 146,20 & $99,86 \%$ \\
\hline 12 & $\begin{array}{l}\text { Government goods } \\
\text { and services n.i.e. }\end{array}$ & 824,20 & $72.415,88$ & $1,14 \%$ & $1.191,80$ & $69,16 \%$ \\
\hline
\end{tabular}

Source: Based on Author's Calculations with Data Retrieved from ITC Trademap Database 
Table 5: India’s Service Trade Statistics (US\$ Million) (2015-2019 Years Average)

\begin{tabular}{|c|c|c|c|c|c|c|}
\hline Code & Service Label & $\begin{array}{l}\text { India's } \\
\text { Export } \\
\text { Value }\end{array}$ & $\begin{array}{l}\text { Global } \\
\text { Export } \\
\text { Value }\end{array}$ & $\begin{array}{c}\text { India's } \\
\text { Percentage } \\
\text { in Global } \\
\text { Export } \\
\end{array}$ & $\begin{array}{l}\text { India's } \\
\text { Import } \\
\text { Value }\end{array}$ & $\begin{array}{c}\text { Export/ } \\
\text { import } \\
\text { coverage } \\
\text { ratio } \\
\end{array}$ \\
\hline 1 & $\begin{array}{l}\text { Manufacturing } \\
\text { services on physical } \\
\text { inputs owned by } \\
\text { others }\end{array}$ & 179,06 & $110.102,36$ & $0,16 \%$ & 47,51 & $376,89 \%$ \\
\hline 2 & $\begin{array}{l}\text { Maintenance and } \\
\text { repair services n.i.e. }\end{array}$ & 184,87 & $91.282,69$ & $0,20 \%$ & 673,13 & $27,46 \%$ \\
\hline 3 & Transport & $17.320,15$ & $948.574,75$ & $1,83 \%$ & $58.329,10$ & $29,69 \%$ \\
\hline 4 & Travel & $26.018,80$ & $1.313 .777,68$ & $1,98 \%$ & $18.778,24$ & $138,56 \%$ \\
\hline 5 & Construction & $2.387,08$ & $103.133,32$ & $2,31 \%$ & $1.656,15$ & $144,13 \%$ \\
\hline 6 & $\begin{array}{l}\text { Insurance and } \\
\text { pension services }\end{array}$ & $2.337,28$ & $130.124,67$ & $1,80 \%$ & $6.021,40$ & $38,82 \%$ \\
\hline 7 & Financial services & $5.031,55$ & $484.421,60$ & $1,04 \%$ & $4.050,09$ & $124,23 \%$ \\
\hline 8 & $\begin{array}{l}\text { Charges for the use } \\
\text { of intellectual } \\
\text { property n.i.e. }\end{array}$ & 661,51 & $370.784,20$ & $0,18 \%$ & $6.557,22$ & $10,09 \%$ \\
\hline 9 & $\begin{array}{l}\text { Telecommunications, } \\
\text { computer, and } \\
\text { information services }\end{array}$ & $57.271,33$ & $557.870,05$ & $10,27 \%$ & $6.261,84$ & $914,61 \%$ \\
\hline 10 & $\begin{array}{l}\text { Other business } \\
\text { services }\end{array}$ & $60.768,65$ & $1.228 .542,63$ & $4,95 \%$ & $36.557,24$ & $166,23 \%$ \\
\hline 11 & $\begin{array}{l}\text { Personal, cultural, } \\
\text { and recreational } \\
\text { services }\end{array}$ & $1.617,23$ & $71.352,91$ & $2,27 \%$ & $2.181,38$ & $74,14 \%$ \\
\hline 12 & $\begin{array}{l}\text { Government goods } \\
\text { and services n.i.e. }\end{array}$ & 606,68 & $72.415,88$ & $0,84 \%$ & 887,53 & $68,36 \%$ \\
\hline
\end{tabular}

Source: Based on Author's Calculations with Data Retrieved from ITC Trademap Database 
Table 6: China’s Service Trade Statistics (US\$ Million) (2015-2019 Years Average)

\begin{tabular}{|c|c|c|c|c|c|c|}
\hline Code & Service Label & $\begin{array}{l}\text { China's } \\
\text { Export } \\
\text { Value }\end{array}$ & $\begin{array}{l}\text { Global } \\
\text { Export } \\
\text { Value }\end{array}$ & $\begin{array}{c}\text { China's } \\
\text { Percentage } \\
\text { in Global } \\
\text { Export }\end{array}$ & $\begin{array}{l}\text { China's } \\
\text { Import } \\
\text { Value }\end{array}$ & $\begin{array}{c}\text { Export/ } \\
\text { import } \\
\text { coverage } \\
\text { ratio } \\
\end{array}$ \\
\hline 1 & $\begin{array}{l}\text { Manufacturing } \\
\text { services on physical } \\
\text { inputs owned by } \\
\text { others }\end{array}$ & $19.728,03$ & $110.102,36$ & $17,92 \%$ & 214,45 & $9199,17 \%$ \\
\hline 2 & $\begin{array}{l}\text { Maintenance and } \\
\text { repair services n.i.e. }\end{array}$ & $6.384,71$ & $91.282,69$ & $6,99 \%$ & $2.359,69$ & $270,57 \%$ \\
\hline 3 & Transport & $39.560,17$ & $948.574,75$ & $4,17 \%$ & $94.380,46$ & $41,92 \%$ \\
\hline 4 & Travel & $40.424,01$ & 1.313.777,68 & $3,08 \%$ & $258.677,66$ & $15,63 \%$ \\
\hline 5 & Construction & $21.564,68$ & $103.133,32$ & $20,91 \%$ & $8.982,29$ & $240,08 \%$ \\
\hline 6 & $\begin{array}{l}\text { Insurance and } \\
\text { pension services }\end{array}$ & $4.574,25$ & $130.124,67$ & $3,52 \%$ & $10.951,41$ & $41,77 \%$ \\
\hline 7 & Financial services & $3.325,32$ & $484.421,60$ & $0,69 \%$ & $2.176,61$ & $152,78 \%$ \\
\hline 8 & $\begin{array}{l}\text { Charges for the use } \\
\text { of intellectual } \\
\text { property n.i.e. }\end{array}$ & $3.844,26$ & $370.784,20$ & $1,04 \%$ & $28.900,61$ & $13,30 \%$ \\
\hline 9 & $\begin{array}{l}\text { Telecommunications, } \\
\text { computer, and } \\
\text { information services }\end{array}$ & $36.187,05$ & $557.870,05$ & $6,49 \%$ & $18.724,07$ & $193,26 \%$ \\
\hline 10 & $\begin{array}{l}\text { Other business } \\
\text { services }\end{array}$ & $64.199,64$ & $1.228 .542,63$ & $5,23 \%$ & $44.577,78$ & $144,02 \%$ \\
\hline 11 & $\begin{array}{l}\text { Personal, cultural, } \\
\text { and recreational } \\
\text { services }\end{array}$ & 928,64 & $71.352,91$ & $1,30 \%$ & $2.851,05$ & $32,57 \%$ \\
\hline 12 & $\begin{array}{l}\text { Government goods } \\
\text { and services n.i.e. }\end{array}$ & $1.453,72$ & $72.415,88$ & $2,01 \%$ & $3.416,17$ & $42,55 \%$ \\
\hline
\end{tabular}

Source: Based on Author's Calculations with Data Retrieved from ITC Trademap Database 
Table 7: USA’s Service Trade Statistics (US\$ Million) (2015-2019 Years Average)

\begin{tabular}{|c|c|c|c|c|c|c|}
\hline Code & Service Label & $\begin{array}{l}\text { USA's } \\
\text { Export } \\
\text { Value }\end{array}$ & $\begin{array}{c}\text { Global } \\
\text { Export Value }\end{array}$ & $\begin{array}{c}\text { USA's } \\
\text { Percentage } \\
\text { in Global } \\
\text { Export } \\
\end{array}$ & $\begin{array}{l}\text { USA's } \\
\text { Import } \\
\text { Value }\end{array}$ & $\begin{array}{c}\text { Export/ } \\
\text { import } \\
\text { coverage } \\
\text { ratio } \\
\end{array}$ \\
\hline 1 & $\begin{array}{l}\text { Manufacturing } \\
\text { services on physical } \\
\text { inputs owned by } \\
\text { others }\end{array}$ & & $110.102,36$ & $0,00 \%$ & & $0,00 \%$ \\
\hline 2 & $\begin{array}{l}\text { Maintenance and } \\
\text { repair services n.i.e. }\end{array}$ & $24.097,80$ & $91.282,69$ & $26,40 \%$ & $7.486,20$ & $321,90 \%$ \\
\hline 3 & Transport & $87.379,60$ & $948.574,75$ & $9,21 \%$ & $100.444,80$ & $86,99 \%$ \\
\hline 4 & Travel & $193.816,80$ & $1.313 .777,68$ & $14,75 \%$ & $118.078,60$ & $164,14 \%$ \\
\hline 5 & Construction & $2.527,80$ & $103.133,32$ & $2,45 \%$ & $2.241,60$ & $112,77 \%$ \\
\hline 6 & $\begin{array}{l}\text { Insurance and } \\
\text { pension services }\end{array}$ & $16.815,60$ & $130.124,67$ & $12,92 \%$ & $49.616,60$ & $33,89 \%$ \\
\hline 7 & Financial services & $125.173,20$ & $484.421,60$ & $25,84 \%$ & $36.302,80$ & $344,80 \%$ \\
\hline 8 & $\begin{array}{l}\text { Charges for the use } \\
\text { of intellectual } \\
\text { property n.i.e. }\end{array}$ & $115.711,00$ & $370.784,20$ & $31,21 \%$ & $41.644,60$ & $277,85 \%$ \\
\hline 9 & $\begin{array}{l}\text { Telecommunications, } \\
\text { computer, and } \\
\text { information services }\end{array}$ & $47.503,20$ & $557.870,05$ & $8,52 \%$ & $41.580,80$ & $114,24 \%$ \\
\hline 10 & $\begin{array}{l}\text { Other business } \\
\text { services }\end{array}$ & $165.696,40$ & $1.228 .542,63$ & $13,49 \%$ & $104.806,60$ & $158,10 \%$ \\
\hline 11 & $\begin{array}{l}\text { Personal, cultural, } \\
\text { and recreational } \\
\text { services }\end{array}$ & $24.128,20$ & $71.352,91$ & $33,82 \%$ & $16.352,40$ & $147,55 \%$ \\
\hline 12 & $\begin{array}{l}\text { Government goods } \\
\text { and services n.i.e. }\end{array}$ & $20.658,40$ & $72.415,88$ & $28,53 \%$ & $22.427,80$ & $92,11 \%$ \\
\hline
\end{tabular}

Source: Based on Author's Calculations with Data Retrieved from ITC Trademap Database 